\title{
Law and the Laboratory: The British Vivisection Inspectorate in the 1890s
}

\author{
Shira Shmuely
}

\begin{abstract}
The 1876 British Cruelty to Animals Act introduced an unprecedented administrative system to supervise any experiment "calculated to give pain" to a living animal. The act, which was in force for a hundred years, established a tight system of control over animal experimentation, including a small, but vigorous, inspectorate. This article explores the relations between bureaucracy and the production of knowledge through the correspondences, memos, and notes taken by two principal inspectors under the act. The inspectors belonged to the worlds of both law and science. Coming from within the scientific profession, their close ties to medical social circles not only evoked critique but also helped them fulfill their tasks and gain access to research laboratories. Archival records examined here for the first time show that, although the inspectors downplayed animals' pain in physiological laboratories, the inspectorate played an important role in shaping the experimental space and practice, thus facilitating the production of "ethical scientific facts." The inspectors' work modeled the new legal regime of animal experimentation regulation, making them indispensable agents in the act's coproduction of knowledge and public order.
\end{abstract}

\section{INTRODUCTION}

On one October morning in 1895, George V. Poore paid a visit to the Neuropathological Department at King's College, London. Resting next to the fire was a monkey, which had had its skull opened three days earlier. Poore, a prestigious physician and an inspector under the British Cruelty to Animals Act 1876, also known as the Vivisection Act, examined the monkey and noted that he could not identify any signs of pain or discomfort. ${ }^{1}$ On the next day, he would take a journey to another registered laboratory, where he would make sure all required licenses and certificates were duly held.

The Vivisection Act was the first law anywhere in the world to impose restrictions on experimentation on living animals through the establishment of a comprehensive administrative system. It translated ideas of moral conduct in animal experimentation into a set of legal previsions, which infiltrated almost every aspect of the physiology

\footnotetext{
Shira Shmuely, Cohn Institute for the History and Philosophy of Science and Ideas, Tel Aviv University, Israel shirashmuely@tauex.tau.ac.il. For their perceptive comments, the author thanks Christopher Capozzola, Stefan Helmreich, Tamar Kricheli Katz, Moran Levi, Joanna Radin, Harriet Ritvo, Maayan Sudai, Jessica Wang, Abigail Woods, Rebecca J. H. Woods, and Lihi Yona. Early drafts of this paper benefited from comments by participants at the meeting of the World Association for the History of Veterinary Medicine, London (2014), the Joint Atlantic Seminar for the History of Biology at Yale University (2015), and Georgetown University Law Center workshop (2015). The author is grateful for the helpful suggestions by the external reviewers of LSI.
}

1. Cruelty to Animals Act 1876, 39 \& 40 Vic., c. 77 (Vivisection Act). 
profession and shaped experimental medicine for a century to come. ${ }^{2}$ As a state intervention in scientific method, the Vivisection Act was preceded only by the British Anatomy Act 1832, which regulated the use of corpses in anatomy studies. ${ }^{3}$ However, while the Anatomy Act had focused mainly on the lawful obtainment of bodies for dissection, the Vivisection Act covered the whole experimental process. Experiments on human beings were unregulated at that time. Britain and other Western countries introduced professional ethical codes or state-sanctioned laws restricting the use of human subjects in research only later in the twentieth century (Grodin 1995). The regulation of animal experimentation is therefore a unique case study for exploring the myriad relations between law and science, bureaucracy, and the production of knowledge.

Analyzing Home Office records and unpublished notebooks, ${ }^{4}$ this article examines how late nineteenth-century inspectors understood and implemented an act that governed, in the act's wording, "any experiment calculated to give pain" to a living animal. I show that the inspectors were hesitant to report to their supervisors at the Home Office about animal suffering in the laboratories they visited but were nonetheless active in educating and directing the physiologists' compliance with the act. Furthermore, the British vivisection inspectors were central to the incorporation of legal norms in the physiological laboratory; moving between the legal and the scientific spheres, the inspectors shaped Home Office policies toward animal experimentation and influenced the work of physiologists. This article argues that, when inspectors guided experimenters to modify their practices in accordance with the regulations for the prevention of cruelty to animals, the civil servants intertwined practical and normative aspects of animal research. The result of the intervention of the Home Office in experimental practice was the introduction of an ostensibly cruelty-free fact or ethical scientific fact. I use "ethical" here in the sense of conformity to moral principles or ethics as well as conforming to the ethics of a profession. ${ }^{5}$

Ethical scientific facts, I contend, are facts about nature that are embedded with the additional administrative authorization that they were obtained through morally acceptable means. In the last couple of decades, historians of science have been preoccupied with examining the construction of scientific facts. In its plainest version, they ask how statements about nature get to be trusted and accepted by the lay public. ${ }^{6}$ I argue that, if experimentation produced scientific facts, regulated animal experimentation produced ethical scientific fact. To clarify, I do not intend to suggest that the work of the inspectors was either ethical or unethical nor that they thought about their administrative role necessarily in those terms. The inspectors' job was to enforce the rules set by the act through a bureaucratic structure. The creation of an ethical scientific

2. In 1986, the Vivisection Act was repealed and replaced by Animals (Scientific Procedures) Act 1986, c. 14.

3. Anatomy Act $1832,2 \& 3$ Will. IV, c. 75.

4. The Home Office is a ministerial department of the UK government with domestic responsibilities. The implementation of the act was the responsibility of the home secretary, who was provided with extensive leeway in designing his department's policy.

5. "Ethic, n. and adj." Oxford English Dictionary Online, www.oed.com.

6. The canonical text in this line of inquiry is still Shapin and Schaffer 1985. 
fact through the Vivisection Act suggests, instead, that the law, when interacting with the scientific practice, produced a certain kind of knowledge about nature.

The analysis is based upon published primary sources as well as archival materials now held by the National Archives in Kew, England. I draw upon abundant internal reports and memorandums written by inspectors and other Home Office civil servants as well as upon outgoing letters from the Home Office to physiologists. The archival collection also includes some valuable historical records of the practice of laboratory visitation, which have not been examined before. Since the late 1880s and the 1890s were formative years in the Home Office's policies regarding the Vivisection Act, inquiry into this period is fruitful for understanding the evolving coproduction of law and science.

The discussion begins with a historiographical section that situates this research in current discussions about the relationship of law and science. It then explores the background of the legislation of the Vivisection Act, followed by an elaboration about the inspectorate and its personnel in the 1890s. These sections show how the inspectors were figures of both scientific and bureaucratic worlds who became agents of coproduction. After this, the article examines the inspectors' testimonies about the animals they saw, showing that they were reluctant to report animal suffering in laboratories even though they closely observed numerous diseased and injured animals. The inspectors' alleged blindness to animal suffering was due to, among other reasons, the difficulties in defining pain. Instead, inspectors focused on procedural breaches of the Vivisection Act and were proactive in educating the experimenters about the act's requirements. The influence of the inspectors was even greater within the research laboratory, where they helped design experimental spaces in the name of animals' well-being. The role of law in the creation of morally acceptable physiological knowledge was epitomized in the inspectors acting as witnesses to live experiments. Qualified witnessing is recognized by science studies scholars to be fundamental to modern science, which explains why the inspectors' role in the laboratories was greater than their role as bureaucratic watchdogs. Starting with the Cruelty to Animals Act 1876 and under the open eye of the inspectors, experimental laboratories generated not only matters of fact but also an ethical science.

\section{THE COPRODUCTION OF LAW AND SCIENCE IN MEDICAL RESEARCH}

A few dominant strands compose "law and science" scholarship. One is predominantly occupied with the application of science in advancing the purposes of the state. This literature explores how states mobilize scientific knowledge to enhance their governing capacities (for example, MacLeod 1965). It explores how particular sciences_-forensic medicine is one example-emerged to facilitate law enforcement. ${ }^{7}$ Another strand of literature is interested in how scientists become involved in policy

7. For example, see Clark and Crawford 1994. 
making and judicial processes as experts and advisers in public, as well as civil, law. ${ }^{8}$ Others in the social studies of law and science examine how legal institutions and norms shaped and transformed science and medicine. ${ }^{9}$

In contrast, the concept of coproduction highlights the joint action of law and science. Science and technology studies (STS) scholar Sheila Jasanoff $(1996,393)$ defines coproduction as "the simultaneous production of knowledge and public order." More than arguing for the reciprocal relations of law and science, the perspective of coproduction seeks to analyze the outcomes of such an interaction as they are manifested in the production of scientific knowledge and public order or "forms of life" (397). Current literature on coproduction is mostly dedicated to questions of science and democratic politics and focuses on issues of risk, representation, and allocation of resources. ${ }^{10}$ Even when sociologist of law Alfons Bora $(2010,14)$ discusses "technoscientific normativity," he develops a critique of the democratic vacuum in participatory processes in science policy. While law and STS scholarship examines "public order" mainly in the sense of formations of citizenship broadly conceived, this article expands on the normative dimension of law in its interaction with science.

Sociologists Susan Silbey and Patricia Ewick (2003) mark another path for understanding the interaction of law and science in their research about environmental and safety regulation. They show that regulation helped to constitute separated places for science and thus legitimized science's claim for objectivity. Regulation, Silbey and Ewick contend, reshaped the very idea of science and its social acceptance. Law is "as much part of the edifice of science as the steel and glass, ducts and ventilating shafts so characteristic of modern laboratory buildings" (Silbey and Ewick 2003, 85). This article adopts the framework of coproduction but shifts the focus away from questions of citizenship. I expand upon Silbey and Ewick's insight into law's embeddedness in scientific practice to include the constitution of moral order within the laboratory. The Vivisection Act shaped both the practical and normative aspects of animal experimentation-more precisely, how these two aspects were interwoven. The act's mission to minimize, or at least monitor, the suffering of animals in laboratories made the law a participant in the creation of a new "cruelty-free" physiological knowledge.

Existing literature on the history of anti-cruelty laws in Britain tends to concentrate on the events and campaigns leading to triumphant legislation. ${ }^{11}$ However, as Daniel Carpenter $(2001,11)$ observes, "legislation cannot hard-wire administrative outcomes." This approach has been prevalent in the work of legal scholars and social

8. For the historical origins of expert testimony, see Golan 2007; for expert witnessing in Victorian courts, see Hamlin 1986; for contemporary analysis, see Jasanoff 1990; on science and courts, see Jasanoff 1997; Burnett 2010. For a collection on British administration and expertise, see MacLeod 2003.

9. For example, see Avraham and Schanzenbach 2015. Catherine Kelly and Imogen Goold's (2009) edited collection explores how British legal process shaped medicine and medical practice.

10. Illuminating examples include Bucchi and Neresini 2007, 453; Rajan 2012; Hilgartner, Miller, and Hagendijk 2015.

11. For example, see Shevelow 2009. While Harriet Ritvo (1987, 135-57) explores the way the Royal Society for the Prevention of Cruelty to Animals (RSPCA) prosecuted offenders under earlier anti-cruelty legislation, her material does not include the Vivisection Act. For an analysis of the role of private associations in enforcing animal regulations, see Wang 2012. Richard French's (1975, 177-206) monograph is the most comprehensive study of the act. French examines the events preceding the act and analyzes its aftermath with regard to the relationships between the Home Office and leading scientific institutions during the first few years of its implementation. 
scientists employing sociological and anthropological methods to account for the regulation of scientific practice. ${ }^{12}$ Tracing the work of the inspectors, who were, according to historian Jill Pellew $(1982,199)$, "in greater contact with the outside world than the higher officials, imprisoned behind their Whitehall desks," provides a valuable perspective on the law in action and, in particular, in action in medical research laboratories.

Debates over the degree and nature of state intervention in nineteenth-century Britain date back to A. V. Dicey's (1905) influential essay entitled Lectures on the Relation between Law and Public Opinion in England during the Nineteenth Century. Dicey's arguments, and his claim for an era of individualism during the mid-century, were challenged by succeeding British specialists (Parris 1960, 26). ${ }^{13}$ One strand in the debate over the history of British governance evolved around the attempt to understand the forces that initiated legislative changes. Reacting to Dicey's emphasis on theories and political ideals, Oliver MacDonagh (1958) suggested a model for government growth based on the dynamic between bureaucrats and the public. ${ }^{14}$ Succeeding publications focused on the nuts and bolts of the nineteenth-century administrative apparatus, encompassing a wide range of fields and activities, including factories, schools, explosives production, and nature conservation (S. Novak 1973; Pellew 1982, 123; MacLeod 1968; Crook 2007).

However, the Vivisection Act has been given little attention by scholars examining the growth of governance in nineteenth-century Britain. There are several possible reasons for this omission. The act differed from other legislation by not demonstrating a direct concern with public safety or economic interests. Instead, it focused on the welfare of animals. Individual rights were not a concern in the debates about state intervention in animal experimentation; here, the main objection of the legislation's opponents concerned the advancement of medicine as a common good (French 1975, 103; Ritvo 1987, 165). Additionally, the administrative system supporting the Vivisection Act was markedly smaller than some of the other inspectorates; ${ }^{15}$ in its first decades, it included only three inspectors responsible for England, Scotland, and Ireland. Nevertheless, the act played a critical role in shaping British medical sciences and hence provides a fruitful case study for nineteenth-century state intervention in scientific practice. The vivisection inspectorate is a story of an unprecedented amalgamation of law and medical research, one in which civil servants reshaped the production of scientific knowledge.

\section{THE VIVISECTION ACT OF 1876}

The enactment of the Vivisection Act was a constitutive moment in animal experimentation in Britain. The act was part of a wave of regulations that concerned,

12. Woods (2004) unravels the relations between British people, veterinarians, and policy makers in response to state monitoring of the use of animals. In this context, see Pemberton and Worboys 2007.

13. P. W. J. Bartrip $(1983,82)$ asserts that state intervention was limited almost all through the nineteenth century but agrees that the regulation in the 1890s had a marked impact. For the historiographical debate on state intervention in the American context, see W. Novak 1996; Ernst 2014.

14. For an analysis of MacDonagh's influence on the related debates, see Cromwell 1966; Mills 2008.

15. For example, compare to the factory inspectorate that in 1878 was constituted by a chief inspector, five superintendent inspectors, thirty-nine inspectors, and ten junior inspectors (Pellew 1982, 151). 


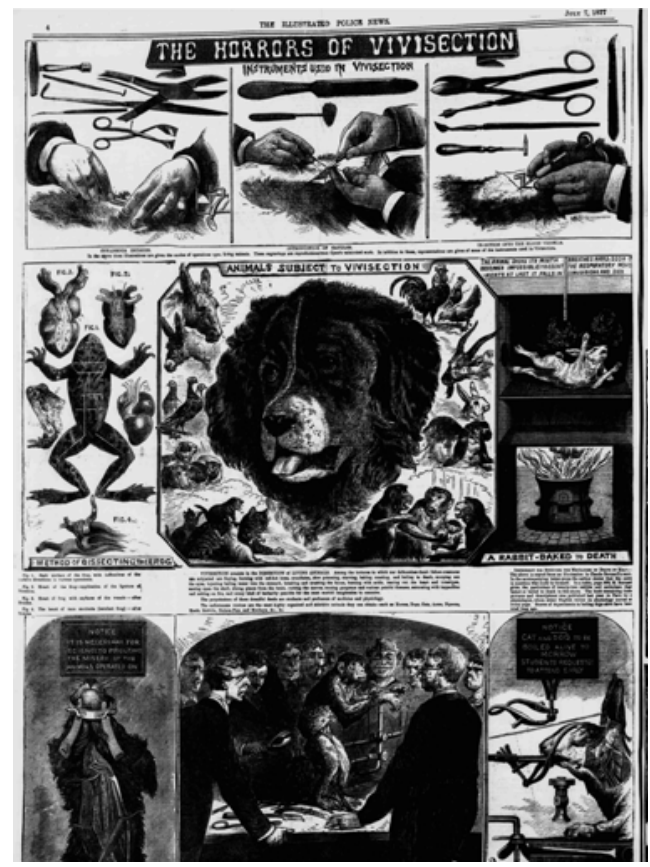

FIGURE 1.

Anti-vivisection agitation: Illustrated Police News. 1877. "The Horrors of Vivisection.” July 7. (C) The British Library Board. All rights reserved. With thanks to The British Newspaper Archive (www.britishnewspaperarchive.co.uk).

in addition to cruelty to animals, conservation, public health (mainly contagious diseases and slaughtering), and nuisance legislation. ${ }^{16}$ British legislators wrestled with the idea of cruelty to animals for decades, as evidenced by the many attempts to amend and refine the offense during the nineteenth century. ${ }^{17}$ Middle- and upper-class patrons embraced the protection of animals as a virtuous position to adopt, while humanitarians used the anti-cruelty movement as an "instrument of marginalization" of the lower classes (Ritvo 1987, 130). ${ }^{18}$ However, animal experimentation was an oddity among the practices attacked by these animal lovers because vivisection practitioners were typically educated gentlemen (Kean 1995, 20).

Public criticism of animal experimentation came to a boiling point in the 1870 s as the practice strengthened its hold in British physiology (see Figure 1). ${ }^{19}$ The Royal Society for the Prevention of Cruelty to Animals (RSPCA), the leading animal protection organization in the United Kingdom, was divided on the issue. Most RSPCA members were convinced that vivisection was necessary for medical progress,

16. For example, An Act to Amend the Law for Regulating Places Kept for Slaughtering Horses 1844 , 7 \& 8 Vic., c. 87; Sea Birds Preservation Act 1869, 32 \& 33 Vic., c. 17; Contagious Diseases (Animals) Act, $1869,32 \& 33$ Vic., c. 70.

17. About the development of nineteenth-century animal cruelty laws, see Harrison 1973.

18. Class dimension and economical calculus are also discussed by Thomas 1983, 185-88. Kathleen Kete $(1995,21)$ describes an analogues process of class formation and the design of Parisian bourgeois identity in the French context.

19. About experimental physiology, see Geison 1978; Coleman and Holmes 1988. 
but some called for its complete abolition. Those opposed to vivisection, a coalition of middle-class reformers, wealthy aristocrats, and clergymen, talked in terms of compassion, benevolence, and religious ideals. ${ }^{20}$ In response to a growing public agitation in which women took the lead, the Home Office summoned the Royal Commission on the Practice of Subjecting Live Animals to Experiments for Scientific Purposes (Royal Commission on Vivisection) in 1875 (French 1975, 236-50; Kean 1998; Ritvo 1987, 157-66; Hamilton 2004; Bates 2017, 45-48). The commission concluded that "the abuse of the practice by inhuman or unskillful persons-in short the infliction upon animals of any unnecessary pain-is justly abhorrent to the moral sense of Your Majesty's subjects." The commissioners therefore suggested legislation as a measure "in the interest both of humanity and of science" (Royal Commission on Vivisection 1876, xviii). ${ }^{21}$

The Vivisection Act was drafted following the recommendations of the Royal Commission on Vivisection. Conservative Lord Carnarvon, the colonial secretary, drafted a bill largely based on a proposal by the RSPCA (Royal Commission on Vivisection 1876, vii). ${ }^{22}$ The bill's enactment was preceded by heated debates between rival interest groups. In the end, the act did not criminalize animal experimentation as the vivisection opponents had hoped, nor did it allow the practice to be independent of oversight, as the vivisection proponents had desired. Instead, the Vivisection Act provided in section 2 that "[a] person shall not perform on a living animal any experiment calculated to give pain, except subject to the restrictions imposed by this Act." The act required experimenters to obtain licenses from the Home Office and to register places where experiments were to be undertaken. It prohibited practices such as dispensing with the use of anesthesia and allowing an animal to recover from an experiment while in pain or serious injury, unless the experimenter obtained a special certificate signed by leading medical authorities.

Section 10 of the Vivisection Act set the legal foundation for the employment of inspectors: "The Secretary of State shall cause all registered places to be from time to time visited by inspectors for the purpose of securing a compliance with the provisions of this Act." The act also allowed the home secretary to "appoint any special inspectors, or may from time to time assign the duties of any such inspectors to such officers in the employment of the government, who may be willing to accept the same, as he may think fit, either permanently or temporarily." The examination of the inspectors' work reveals that the act was not a dead letter law (compare Ritvo 1987, 160). Inspectors George Vivian Poore (1843-1904) and James Alexander Russell (1846-1918), who were on duty in the last decade of the nineteenth century, left handwritten and typed notebooks with their impressions from inspection visits. Their notes from the years 1894, 1895, 1897, and 1899

20. About anti-vivisection rhetoric and ideals, see Ritvo 1987, 163-66; Guerrini 2008; Bates 2017, 45-48. About Victorian attitudes toward animal pain, see Turner 1980.

21. The second Royal Commission on Vivisection $(1912,57)$ concluded: "[E]xperiments upon animals, adequately safeguarded by law, faithfully administrated, are morally justifiable and should not be prohibited by legislation."

22. The mainstream RSPCA was in support of the law after its enactment as well, notwithstanding the many faults found in its enforcement. RSPCA, "Précis of Evidence to be Given before the Royal Commission on Vivisection," 1907, Home Office (HO) 144/4, Home Office Correspondence 1782-1979, The National Archives, UK. In 1875, an oppositional group within the RSPCA established the Victoria Street Society, which promoted the total abolition of vivisection. 
provide a rare glimpse into how the Vivisection Act worked in practice. ${ }^{23}$ In what follows, I focus on Poore and Russell to provide an in-depth analysis of a reasonable time frame.

\section{THE VIVISECTION INSPECTORATE}

Inspection was developed as a tool of the British central government in the mid-nineteenth century. By the time the Vivisection Act was released, there were ten inspectorates working under the Home Office, monitoring a range of areas from factories and mines to burial grounds and salmon fisheries (Pellew 1982, 12). ${ }^{24}$ The concept of inspection was familiar to nineteenth-century men of medicine from the Anatomy Act 1832, and most of the witnesses who testified in front of the Royal Commission on Vivisection expressed no objection to the idea of inspection. The physiologists' responses reflected their experience with the Anatomy Act's inspectors, whose main responsibility was to ensure that dissected human corpses were obtained lawfully (Royal Commission on Vivisection 1876, 54). Nonetheless, for the Vivisection Act, the commission rejected the vision of a minimal and formalistic inspection system in the spirit of the Anatomy Act and, in its 1876 report, recommended that greater responsibility be given to the inspectors of vivisection. The commission advised that places where animal experimentation was undertaken should be registered and that the home secretary be given the means to make a "most efficient inspection" of such premises (Royal Commission on Vivisection 1876, 54).

The Vivisection Act did not explicitly prescribe any duty other than visiting registered places, but, in practice, inspectors were involved in much more. At the core of the implementation of the act were the day-to-day activities of the Home Office inspectors and their encounter with animals subjected to research. In addition to laboratory visitations, the inspectors' responsibilities included advising the home secretary, communicating with experimenters, and gathering and organizing data for annual reports presented to Parliament. The inspectors composed reports with direct implications for laboratories. For example, following an 1888 memorandum by Inspector John Erichsen, the Home Office added a condition to licenses requiring the use of antiseptics in certain procedures, aiming to ease the pain of animals recovering from surgeries (Royal Commission on Vivisection 1912, 7). However, the inspectors were not given any authority to begin legal proceedings for violations of the act perhaps because of the inflammatory potential of prosecuting physiologists. ${ }^{25}$ The home secretary, who held the authority to prosecute, relied heavily on the work of the inspectors in gathering and processing information about the state of affairs in laboratories and designing the office's policies.

23. To the best of my knowledge, the only other surviving visitation reports are by inspector George D. Thane (1850-1930).

24. Gerald Rhodes (1981, 3, 247) distinguishes between "enforcement inspectors," who ensure compliance with statutory requirement, and "efficiency inspectors," who supervise certain activities of other authorities. Rhodes classifies the vivisection inspectors as enforcement inspectors.

25. Legislators were well aware of the events surrounding the 1874 case known as the "Norwich Trial," in which an animal protection organization prosecuted physiologists for violating an anti-cruelty law prior to the Vivisection Act (Hamilton 2004, xvi). 
The inspectors' visits to laboratories lasted anywhere between two hours and an entire day. It was left to the discretion of the inspectors to decide whether to inform the licensees about the anticipated inspections: in 1894, for example, the number of scheduled visits equaled unscheduled visits. ${ }^{26}$ During 1895 , James Russell made all of his visits without an appointment, with one or two exceptions. He explained to George Poore that he preferred not to be tied to a day and added that it would improve credibility with anti-vivisection protestors to be able to report that most inspections took place without advance notice. ${ }^{27}$ The number of visits to each registered place varied. Although Home Secretary Henry Matthews was quoted to have said on one occasion that "the words 'from time to time' in the Act have been interpreted in the Home Office to mean once a year," Matthews claimed on another occasion that "two or more visits a year were expected to be made by the inspector" if experiments were being carried out. ${ }^{28}$ Visiting laboratories was a delicate task as inspectors needed to smoothly move between the bureaucratic and the scientific spheres.

\section{"HIGH INFLUENTIAL POSITION ... AND IN THE VIGOUR OF LIFE": ELECTING INSPECTORS AND THE PROBLEM OF ADMINISTRATIVE CAPTURE}

Because the attempts to regulate vivisection enraged many experimenters and generated major institutional resistance (French 1975, 118-58; Ritvo 1987, 57-160), officials emphasized the importance of ensuring that the inspectors be personally agreeable. The Royal Commission on Vivisection $(1876,221)$ indicated that the inspectors should be "persons of such character and position as to command the confidence of the public no less than that of men of science." During the preparation of the vivisection bill, members of the medical establishment joined forces to mitigate the potential interference in their work, using their ties with Parliament members and the public platform provided by medical journals (French 1975, 118-42). The General Medical Council wished to amend the vivisection bill to ensure the employment of inspectors who were "scientifically competent to appreciate the nature and intention of such experiment as he may witness." 29 This recommendation did not make its way into the act but was unofficially followed by the Home Office administration in practice in order to achieve legitimacy among experimenters. Another consequence of the policy to appoint inspectors with scientific training was that the elected inspectors, inhabiting both worlds of bureaucracy and of science, were effective in fostering the law and science coproduction of ethical scientific facts.

Home secretaries recognized that the character of the inspectors was crucial in legitimizing their reports in the eyes of experimenters. The Home Office sought to

26. "Memo on Inspection under the Cruelty to Animals Act," 1902, HO 144/634/B37080.

27. James Russell to George Poore, March 5, 1896, HO 144/383/B19846A.

28. "Memo on Inspection"; Secretary of State to the Secretary, H.M. Treasury, December 12, 1890, HO 156/6, 46.

29. General Medical Council, "Memorial from the General Medical Council to Her Majesty's Government Respecting the Bill Intituled [sic] 'An Act to Prevent Cruel Experiments on Animals,"' n.d., file 2021/7, 5, Royal College of Physicians, London. 
establish institutional legitimacy by recruiting inspectors from within the supervised professions, expecting that those with such professional backgrounds could produce credible testimony about the state of animals in laboratories. Home Secretary Henry Matthews maintained in 1890 that the inspectors' duties "cannot be performed except by a gentleman who has high influential position in his profession and is in the vigour of life." ${ }^{30}$ In the Vivisection Act's first few decades, the Home Office recruited inspectors with medical training, who were also involved in research and served on educational or public institutions related to their scientific expertise. ${ }^{31}$ The scientific background of the inspectors played a role in making them agents of coproduction; being scientists who communicated with other scientists, they facilitated the flow of information about animals' bodies between the Home Office and physiologists. Being legal actors, this flow also carried with it norms of conduct.

The stated aim was to find gentlemen who would be viewed as credible by both the scientific community and the wider public, which was envisioned to include many critical perspectives on vivisection. However, it is evident that the satisfaction of the scientific community was a top priority. Home Secretary Herbert Asquith defended the importance of scientific training for the inspectors and said that, while the act only required the inspection of a registered place, "the inspector would not be doing his duty properly were he not to make himself personally acquainted with the matter in which the experiments themselves were conducted." Asquith added that inspectors "ought not however to look on the eminent scientific men who conducted these experiments as if they were criminals caught out at attempted infractions of the law." 32 It is hard to overstate how meaningful this last notion was for the scientific community. The original skepticism of physiologists gradually decreased when it became clear that inspectors would have ties to the scientific enterprise. The experimenters' discontent with the administration of the act was aimed mainly at the home secretary rather than at the inspectors. Pathologist Charles S. Roy from the University of Cambridge remarked that the first three inspectors "have admirably fulfilled their duties as inspectors." Nevertheless, he argued that their mandate in advising the home secretary should be limited, as "none of them had the laboratory experience required to enable them to act as efficient experts." 33

The requirement that inspectors have a scientific background, in addition to generating legitimacy among experimenters, also reflected the emerging centrality of scientific knowledge in defining British attitudes toward animals. Sir William Church, the president of the Royal College of Physicians, voiced the position held by scientific

30. Secretary of State to the Secretary, December $12,1890,50$. In this article, I examine the implementation of the Vivisection Act under Home Secretary Henry Matthews, who was in office from 1886 to 1892; Home Secretary Herbert H. Asquith, who was in office from 1892 to 1895; and Home Secretary Matthew White Ridley, who was in office from 1895 to 1900 . The three home secretaries played an active role in implementing the act. In 1886, Matthews instructed that any case in which a considerable amount of pain might be inflicted, or which involved cats, dogs, or monkeys, should be brought to his personal notice Godfrey Lushington to Stapleton, November 24, 1886, HO 144/17/44209X. In 1893, Asquith stated: "[T]here is no part of my duty that gives me greater solicitude, or to which I pay, as time allows, more constant attention" than the administration of the Vivisection Act. 17 Parl. Deb. (4th ser.) (1893) col. 343.

31. Veterinary doctors, who had a lower status in the scientific milieu at that period, were qualified to serve as inspectors much later in the twentieth century (Home Office 1980, 12).

32. "Memo on Inspection."

33. Charles S. Roy to the Secretary of State, October 28, 1893, HO 144/315/B7414A. 
institutions when he wrote in 1899: "I feel certain that if a layman were appointed inspector there would be a general uprising of the profession of scientific teachers and men throughout the kingdom." Church explained that by layman he meant "a lawyer or other person who had not gone through a complete scientific training including either physiology or medicine." 34 Church specified that the inspectors should not only be men of science but also trained in specific fields. In his view, a background in physiology and medicine was necessary to accurately understand the tasks demanded of experimenters in laboratories. A mastery of these disciplines was also required to produce a credible evaluation of the suffering of animals in laboratories. The inspectors' medical training qualified them as expert witnesses of animal pain.

The first inspector under the Vivisection Act was George Busk, a respected surgeon and a naturalist in his seventies. He was a fellow of the Royal College of Surgeons and held the chair of Hunterian Professor of Anatomy and Physiology before serving various offices at the college. Busk was involved with several scientific societies: he was a fellow, and also served on the council, of the Royal Society and was a member of the Linnaean, the Geological, and the Zoological societies (British Medical Journal 1886). The anti-vivisection journal, the Zoophilist $(1886,4)$, however, contended that Busk had been "remarkable for nothing but mediocrity," and his inspection was "a sham." For tasks that required traveling outside of London, Busk employed an assistant, G. J. Allman.

Surgeon John Eric Erichsen replaced Busk on April 1, 1886. His resume was as distinguished as Busk's: he was a fellow of the Royal College of Surgeons and occupied high positions at the institution. Erichsen was elected a fellow of the Royal Society in 1876, and, in 1877, he was made surgeon-extraordinary to the queen. Erichsen was a commissioner at the Royal Commission on Vivisection of 1875 and was considered a neutral nominee, although he had previously experimented on animals. He even managed to gain the trust of Commissioner Richard Holt Hutton, a leading antivivisection spokesman (French 1975, 96). But Erichsen (1879) did not identify himself with the anti-vivisection cause.

George Poore first joined the Vivisection Act's administration on April 1, 1889 to assist Inspector Erichsen. ${ }^{35}$ A member of the medical elite, he had been a fellow of the Royal College of Physicians since 1877. He also had a special interest in public hygiene and was a member of the Executive Council of the International Health Exhibition held in London in 1884. He held the position of physician at University College Hospital, where he was also the chair of medical jurisprudence and clinical medicine (British Medical Journal 1904, 1544; 1905, 1398). On May 12, 1890, upon the resignation of Erichsen, Poore was promoted to the rank of inspector. ${ }^{36}$ Poore soon experienced the increasing workload of the inspectors: in 1888, there were seventy-five licensees and twenty-eight institutions, in which one or more laboratories were licensed to conduct experiments. In 1889, there were eighty-seven licensees and thirty institutions, and, in 1890, the year in which Poore became an inspector, the number of licensees had

34. "Memo on Inspection."

35. Godfrey Lushington to the Secretary of the Treasury, April 4, 1889, HO 156/4, 574.

36. Inspectors were chosen by nomination and not by competition. Letter on behalf of the Secretary of State to Mr. Jones, December 29, 1891, HO 156/6, 580. 
increased to 110 and the number of institutions to thirty-three. ${ }^{37}$ The steady growth in requests for licenses and registration led Poore to suggest to Home Secretary Henry Matthews that an assistant inspector be engaged with the responsibility of Scotland and Newcastle, leaving England south of York in his mandate as the principal inspector. ${ }^{38}$ Poore's request was granted, and James Russell was hired as assistant inspector for Scotland and North England. Russell was trained in medicine and sanitation and was engaged in public health management in Edinburgh. In 1881, he had been elected a fellow of the Royal College of Physicians, and, at about the same time, he was appointed government inspector of anatomy for Scotland (British Medical Journal 1894, 1216). Russell began his duties as an assistant inspector to Poore on August 1, 1890.

There were inherent complexities in the inspectors' role in interacting with the people whose work they supervised and whose careers they could damage. Although the licensees were obliged by law to allow the inspectors to examine the registered places where they operated, a cooperative attitude benefited the inspectors' work. As in other inspectorates, a substantial part of the inspectors' role in relation to the experimenters was explanatory and advisory. ${ }^{39}$ Historian Gerald Rhodes $(1981,64)$ observes in his study of late nineteenth-century factory and mines inspectors that "[they] relied on persuasion rather than prosecution." Along the same lines, historian Tom Crook $(2007,372)$ claims in his study of sanitation inspectors that "public diplomacy was crucial" and relations with the public determined whether the inspectors' job would be relatively easy or "slow and confrontational." When Poore, for example, visited the Pathological Department at Cambridge University, James Lorrain Smith asked him if putting a mouse in a jar before a class in order to collect the gases produced through respiration was an experiment. Poore replied negatively, explaining that he did not think it was an experiment calculated to inflict pain. ${ }^{40}$

The encounters between the inspectors, the licensees, and other laboratory personnel included discussions of shared interests and provided opportunity to educate the experimenters about the Vivisection Act's requirements. Shortly after Russell had begun his work, Poore told him that he "was not expected to act as a detective" (Royal Commission on Vivisection 1907, 22). Indeed, Russell promised Thomas Oliver from Newcastle, who was doing electric shock experiments on dogs, that he would help to obtain some information Oliver needed from the Edinburgh Corporation's electrical engineers. ${ }^{41}$ Russell visited Oliver in his home as well as the homes of other experimenters. ${ }^{42}$

37. Experiments on Living Animals, 1889, H.C. 114, 3; Experiments on Living Animals, 1890, H.C. 150, 3; Experiments on Living Animals, 1890, H.C. 266, 435.

38. Letter on behalf of the Secretary of State to the Secretary, H.M. Treasury, December 12, 1890,

HO 156/6, 47. Records show that an additional assistant was employed to assist George Poore.

39. Pellew $(1982,125)$ makes a similar claim in reference to factory inspectors.

40. George Poore, "Dr. Poore's Report on Visitation of Registered Places during 1894," 1895, HO 144/370/B17451A, 1 (Poore, "Dr. Poore's 1895 Report”).

41. James Russell, "Russell's Report in Dr. Poore's Report on Visitation of Registered Places during 1894,” 1895, HO 144/370/B17451A, 7 (Russell, "Russell's 1895 Report”).

42. James Russell, "Russell's Report in Dr. Poore's Report of Inspection of Registered Places in 1895," 1896," HO 144/383/B19846A, 14 (Russell, "Russell's 1896 Report"); James Russell, "Inspection of Registered Places in Great Britain 1897," 1898, HO 144/419/B25696A, 8, 12, 14; James Russell, "Reports of Visits to Registered Places for Year 1899," 1900, HO 144/451/B30824, 22. 
The strategy of employing familiar and respected figures in the scientific community who were versed in the medical sciences evoked undesired, perhaps even unexpected, opposition. Historian of science Steven Shapin (2010, 23-46) describes how, for a long period, scientists had enjoyed a privileged position in relation to public affairs that was later transformed into "moral equivalence." However, historians Anita Guerrini (2003, 87-92), Coral Lansbury (1985, x), and Harriet Ritvo (1987, 163) reveal that many British individuals distrusted medical institutions for their abusive treatment of lower-class women and their use of poor populations. For late nineteenth-century criticizers of vivisection, being a man of science not only was unrelated to having a special moral standing but also was seen as disqualifying a person from expressing views on public issues.

The Vivisection Act's opponents maintained that the inspectors were too closely attached to their subjects of supervision and too embedded with the values, interests, and goals of the scientific establishment to ensure a disinterested inspection. In a debate at the House of Commons in September 1893, Colonel Amelius Lockwood, a conservative member of parliament (MP) for Epping, claimed that the inspectors "were supposed to stand between the vivisectors and their subjects, the dumb animals, in order to assure ... the claims of the lower animals to human consideration." MP Lockwood argued that the inspectors were insufficient in this regard-first, because they held other occupations in addition to being inspectors and, second, because they were not sufficiently detached from the subject. Lockwood pointed out that Inspector Poore, whom he acknowledged to be "universally respected," had held a position at the University College Hospital and that "a gentleman who was constantly in association with 16 men engaged in the work of vivisection could hardly be regarded as perfectly impartial." Lockwood recommended that future inspectors be appointed in consultation with the RSPCA. Home Secretary Herbert Henry Asquith smiled when he heard Lockwood's proposal: "I am afraid that if I had to arrive at a conclusion with the Anti-Vivisection Societies we should remain without any inspector at all."43

The Vivisection Act's administration demonstrated the classical problem of regulatory capture, whereby the regulator agents have an interest in protecting the very entity they are charged with regulating. Jill Pellew $(1982,198)$ notes that, perhaps more than any other inspectorate at that time, the vivisection inspectors were "closer to those they were inspecting than to their official colleagues" in the Home Office. An inspector in such a position, Pellew suggests, might have "overlooked some small infringements of the act in the interests of his own profession" (198). ${ }^{44}$ At the same time, what critics of the act's administration might have interpreted as an unduly intimate relationship between inspectors and experimenters might also have been a way to ease potential tensions as they fulfilled their mission. The inspectors tried to mediate between experimenters and policy makers, examine all registered places, and report deviations from the law while maintaining congenial relationships with the experimenters so as to enjoy relatively free access to animal rooms, demonstration rooms, and even the performance of experiments. The inspectors were legal agents with scientific credentials who moved

43. 17 Parl. Deb. (4th ser.) (1893) cols. 333, 334, 344.

44. Pellew $(1982,198)$ points to anatomy inspectors and vivisection inspectors as the most prone to side with the institutions they were inspecting. 
back and forth between the Home Office and the laboratories, navigating between law's requirements and scientific demands. In the next sections, I map and analyze where and when inspectors minimized or alternatively reinforced their intervention in the vivisection laboratory.

\section{“THERE CAN BE NO PAIN”: INSPECTORS MEET ANIMALS}

Pain was the leading category of reference for the inspectors. Section 3 of the Vivisection Act imposed restrictions "with respect to the performance on any living animal of an experiment calculated to give pain." These restrictions included, among others, subsection 3(3): "The animal must during the whole of the experiment be under the influence of some anaesthetic of sufficient power to prevent the animal feeling pain," and subsection 3(4): "The animal must, if the pain is likely to continue after the effect of the anaesthetic has ceased, or if any serious injury has been inflicted on the animal, be killed before it recovers from the influence of the anaesthetic which has been administered." Additionally, annual reports about licensed experiments carefully distinguished between painless and painful experiments.

In their visits to laboratories, inspectors attempted to evaluate whether the animals they saw-whether undergoing an experiment or recovering one-suffered pain and, if they did, to what degree. Historian Roy MacLeod $(2003,14)$ observes that inspectorates in Britain "were acting as the 'eyes and ears' of government," but the vivisection inspectors were not only witnesses and record keepers, they also made judgments about animals' well-being and proper conduct in the research laboratory. Their visitation notebooks bring fresh perspective as they provide an informal record of the inspectors' practice and, together with memos and correspondences with the civil servants at the Home Office and with physiologists, afford a sense of the everyday life of the law.

Pain is not a self-evident phenomenon, and, in nonhuman animals, which cannot articulate their experiences in words, it is even more so. The Vivisection Act did not define "pain" or "suffering," nor did nineteenth-century courts, which confronted a similar challenge in cases of cruelty to animals. ${ }^{45}$ Scientists could not provide civil servants with a clear-cut definition of pain or suffering either since physiologists debated where to locate and how to recognize pain (Rey 1998, 182-260; Bourke 2014, 272-302). The state of knowledge about pain in that period was showcased in the report of the Royal Commission on Vivisection. Scientific consensus gradually attributed pain to the workings of the nervous system. Nevertheless, many scientists who testified in front of the commission contended that the intensity of pain, and, at times, even the existence of the sensation itself, varied across animal breeds and human races (for example, Royal Commission on Vivisection 1876, 25, 136).

Having a certain idea of pain and a way to detect it, measure it, and talk about it were fundamental for anyone engaged with the Vivisection Act and especially for the inspectors who were trusted to supervise its implementation. Nevertheless, the act did not define "pain," as it did not define an "experiment." Without concrete guidelines for

45. The list of experts for the question of pain in a cruelty to chickens case included a veterinarian as well as a painter. Murphy v. Manning, (1877) 2 Exch. D. 307. 
the detection of pain in laboratory animals, the civil servants used a mixture of intuition, personal knowledge, data received from physiologists, and Home Office precedents to decide whether the animals they saw were suffering pain and to what degree. They decided, for instance, which degree of pain was tolerable for the act and whether, for instance, a mutilated animal was in pain. The meaning of pain in the context of the Vivisection Act was thus constructed through the interplay of law and science.

Inspectors used various strategies to evaluate animal suffering. They examined some animals visually; at other times, they looked for changes in indicators of pain such as appetite or playfulness. On other occasions, an animal's physiological inability to feel pain, rather than visual indicators, convinced the inspectors that the animal was not suffering. In a visit to the Brown Institution in January 1894, Poore saw some cats whose posterior nerve roots had been divided by the physiologist and future Nobel Prize winner Charles Sherrington. Poore noted in his report that "the operation deprived the animal of feeling in the earlier operation and causes some motor disability. There can be no pain." 46 Poore's decisiveness about the lack of sensitivity of the cat was probably related to Sherrington's established reputation as a neurophysiologist.

Poore encountered monkeys quite often, and he almost always took their energetic behavior as a sign of well-being. In 1894, Poore visited Charing Cross Hospital Medical School. "Saw some monkeys which were said to have been experimented on," he noted in his book, "saw nothing noticeable about them." 47 In a later visit, he saw a monkey that had had an operation performed on its cerebellum. Poore carefully scrutinized the body of the monkey and found "a slight deficiency of power in left hind leg." Four months later, Poore described one of the monkeys that he had seen before as "perfectly happy." 48 In January 1895, Poore visited Charing Cross Hospital Medical School again. Neither physiologist Frederick Walker Mott nor his assistant, whom he had expected to see, was there to welcome him. The animals' room, however, was open, and Poore walked in to examine the animals. A suggestion of familiarity appears in his remark that the same monkey he had seen before was "as lively and friendly as usual." 49

Poore consistently wrote positive reports, but his records reveal a more complex reality of mutilated animals. When Poore visited St. Thomas' Hospital in 1894, he saw two monkeys whose posterior nerve roots had been divided by Sherrington. They were probably rhesus macaques on which Sherrington was exploring questions of motion and reflex action (Mott and Sherrington 1894, 481). The monkeys had lost sensation or useful action in one of their hind limbs, and yet Poore could find no signs of suffering: "The animals were chattering and lively and certainly in no pain." On another visit to St. Thomas' Hospital, he saw a monkey that had some of its posterior nerve roots divided. He reported that neither the monkey nor several cats whose thyroid glands were removed seemed to be suffering. A few months later at the same institution he saw a monkey that "had its 'third nerve' divided. Its left eyelid drooped a

46. Poore, "Dr. Poore's 1895 Report," 39.

47. Poore, "Dr. Poore's 1895 Report," 31.

48. Poore, "Dr. Poore's 1895 Report, 32, 33.

49. George Poore, "Dr. Poore's Report of Inspection of Registered Places in 1895," 1896, HO 144/383/ B19846A, 7 (Poore, "Dr. Poore's 1896 Report”). 
little but as soon as its cage door opened it caught hold of the window rope and ran up it as only a monkey can." 50

Poore rarely recorded inactive or frail monkeys. One of these encounters took place when he visited the Neuropathological Laboratory in King's College. Among all registered places, this facility was the hardest to get access to. Poore's earlier attempts to visit the site in May 1894 had failed since the laboratory was locked. ${ }^{51}$ Finally, in October 1894, he was able to enter the place. The single licensee associated with the place at that time was David Ferrier, ${ }^{52}$ who had been prosecuted a decade earlier by the Victoria Street Society for violating the act; the charges against him were dismissed by the Bow Street Court (British Medical Journal 1881, 841). Poore encountered four monkeys, one of which had been trephined (a drilling of a hole in the skull) three days before. It was sitting in front of a lit fireplace. Poore looked at the monkey and concluded that it "afforded no evidence whatever of pain or discomfort." 53 He visited again the following year and saw a monkey that had had portions of its brain removed: "The animal was lively and active," though he noticed some problem in the hind legs. A few months later in the same place he saw a monkey that had had the motor cortex of the brain removed, "but it was quite nimble and in no suffering." 54

Unpleasant sights were almost always absent from Poore's reports. The descriptions of the animals he saw were never harsher than, for example, a comment that a cat whose thyroid gland had been removed ten days earlier was "perhaps slightly sluggish in its movements." When he visited the Pathological Laboratory at London University College in January 1894, Poore saw a female dog from which half of the cerebellum had been removed some months ago. She was "happy and very proud of a puppy, the last of a litter of healthy pups she had recently brought forth." This kind of description was typical for Poore. When he saw a rabbit at University College in Liverpool, in which the sciatic nerve had been divided, he commented that it was "able to go about quite naturally and was in no discomfort." 55

Similarly, Assistant Inspector Russell's visitation notes were composed from short descriptions of the animals he had seen followed by his almost-always positive impressions of their well-being. Russell was most enthusiastic about the laboratory in Newcastle. He was impressed by the handling of the animals, which, besides monkeys, included dogs, rabbits, guinea pigs, and white rats, all, according to Russell, "in vigorous health, comfortably housed, well-fed and tame." ${ }^{56}$ During a visit in November 1895 , Russell met with Thomas Oliver (1891), who was at that time primarily engaged with lead poisoning experiments, concerning his certificates. A day after the meeting, he sent Poore "a special report" on the condition of the animals experimented upon by Oliver; Poore then forwarded it to the Home Secretary. ${ }^{57}$

50. Poore, “Dr. Poore's 1895 Report,” 25, 26, 27.

51. Poore, "Dr. Poore's 1895 Report," 16.

52. Experiments on Living Animals, 1894, H.C. 103, 13.

53. Poore, "Dr. Poore's 1895 Report," 18.

54. Poore, "Dr. Poore's 1896 Report," 20.

55. Poore, "Dr. Poore's 1895 Report," 4, 6, 19.

56. Russell, "Russell's 1895 Report," 10.

57. Russell, "Russell's 1895 Report," 10; see also Letter on behalf of the Secretary of State to George W. Poore, November 27, 1894, HO 156/9, 111. 
The inspectors did not leave behind detailed criterions for judging the condition of animals, and they probably did not have any. Yet Russell explained that a loss of appetite was "the first and most valuable index that we have for the condition of feeling" (Royal Commission on Vivisection 1907, 25). Reflecting back on his sixteen years of duty, Russell described his guidelines for identifying pain:

My own private opinion is that whatever would affect the appetite or raise the temperature of an animal must be held to give some degree of pain, or of uneasiness amounting officially to pain. In some cases practically the only indication that the animal is suffering from anything is to find that the temperature is somewhat raised; or that the animal is losing flesh. I think want of appetite and loss of flesh are even better guides in the lower animals than they are in man. I do not mean to say that in every case of that sort there is severe pain. In my précis I have stated that it is a pain comparable to that felt by a human being suffering from diseases which would cause similar effects. (23)

The inspectors' reports conveyed their voices, and the archives contain only the descriptions of the experimental animals as the inspectors saw them. For the most part, to elicit perspectives other than the ones they provided, we can only try to read the inspectors' notes "against the grain" in order to deduce what information may have been omitted from their observations. However, the following case offers a rare opportunity to compare Russell's point of view with another revealing source.

In reports of visits during 1894, Russell mentioned two rabbits belonging to physiologist George Murray, which he had seen before. Their thyroids had been removed long ago, but they were "well and lively." 58 In a later visit, Russell noted that "a rabbit which had the thyroid removed by Dr Murray two years ago was very fat." ${ }^{59}$ But the physiologist's portrayal of the experiments reported by Russell evoked a very different image of the animals he used. In an 1896 British Medical Journal publication, Murray (1896, 205) described the February 1893 removal of the thyroid gland from a black and white doe rabbit: "A month after the operation the rabbit had become rather dull and inactive, but it could be easily roused to active movements. A week later the appetite diminished considerably. ... Then during February 1894, a good deal of the hair on the ears, and nose was shed. ... The rabbit began to suffer from uterine haemorrhage and so it was killed."

The dates of this experiment and Russell's visits coincide, and chances are high that Russell saw the same rabbit that Murray had written about. Did Inspector Russell not see the cracks on the animal's skin? Did he not notice that it was "generally found sitting still with the eye half closed?" (Murray 1896, 205). In the same publication, Murray also remarked that monkeys after thyroidectomy suffer from similar symptoms of lethargy, swelling, reduced appetite, loss of hair, dryness of skin, and low temperatures. Did Russell see all this and yet decide to omit it from his report? Or did he think that these symptoms did not constitute suffering under the 
Vivisection Act? It is evident that Poore and Russell were reluctant to record indications of animal pain. As Murray's (1896) essay on rabbits showed, the inspectors might neglect to report troubling situations or, worse, turn a blind eye to cases of possible suffering. To a large extent, their avoidance reflected the inspectors' inclination to favor the experimenters and to protect their colleagues' reputations. In other words, they demonstrated administrative capture. But their caution with reporting about animals in pain also indicated their caution about asserting their views relating to issues in a field of knowledge that was increasingly ascribed to the realm of science (Dror 1999).

Animal suffering, if the inspectors acknowledged it at all, was seldom included in their reports, but they translated it to a set of procedural requirements. As the next section will show, the inspectors used their power to the fullest when confronted with mundane bureaucratic breaches of the Vivisection Act, such as the lack of a proper license or an expired certificate. The inspectors constructed pain as an object of regulation not by a direct identification and handling of the suffering body but, rather, through the creation of various other means-such as a meticulous enforcement of procedural requirements, the education of physiologists about the act, and intervention in the design of the experimental space-in the name of animals' well-being. Through this bureaucratic oversight, the inspectors facilitated the incorporation of the standards of behavior prescribed by the Vivisection Act.

\section{INFRINGEMENTS}

Visits to laboratories were a central method for revealing infringements relating to experiments without the required authorization. Inspectors would ask experimenters to produce certificates relating to the animals he had seen in the laboratory. In cases where the experiments did not require certificates, the inspectors would examine the physiologists' licenses to make sure that they were up to date. Poore included two infringements of the Vivisection Act during 1894 in his annual report to Parliament. The licensees, he explained "carelessly exceeded the powers given to them by their certificates." ${ }^{\circ}$ One of these infringements was discovered when Poore visited the Charing Cross Hospital Medical School, where he saw a dog on which neuropathologist Frederick Walker Mott had made a central incision in the spinal cord. Mott did not have the proper certificate for this experiment, "but this was reported at the time and settled." 61

In mid-November 1895, Poore visited the Pathological Laboratory at the Army Medical School in Netley, where he met the bacteriologist and immunologist Almroth E. Wright. He had observed a rabbit dying "perfectly tranquilly" as a result of subdural inoculation of hydrophobia (rabies) ten days earlier. However, allowing an animal to recover from the influence of anesthetic after an experiment required a special certificate; Poore ascertained that Wright did not hold the appropriate certificate to cover the procedure and informed the Home Office. ${ }^{62}$ Wright argued that he had obtained the correct certification but failed to include the specific operation on the rabbit. Home Secretary Matthew Ridley accepted Wright's explanation, and, following

60. Experiments on Living Animals, 1894, H.C. 103, 41.

61. Poore, "Dr. Poore's 1895 Report," 7, 32.

62. Poore, "Dr. Poore's 1896 Report," 43. 
an arrangement made between Poore and Wright, he requested that Wright submit a corrected certificate. ${ }^{63}$

Not all experimenters were as lucky as Mott and Wright. On January 11, 1895, Poore visited the examination rooms of the Royal Colleges of Physicians and Surgeons in London. In the animal room, among various guinea pigs and rabbits, one cat caught his attention. Experimenter Fenwick had created a gastric fistula in the cat a few days previously, but the cat seemed to Poore to be "unconscious of its condition." ${ }^{4}$ Poore had the cat taken out of its cage and noted that it was "quiet and purring and rubbed its head against my closed hand as often the manner of cats when we think they are pleased." However, four days later, Poore returned and informed the director of the institution, German S. Woodhead, that Fenwick had performed the experiments without the certificates that were required: first, to experiment without anesthesia and, second, to keep an animal alive after the experiment. Poore and the director went together into the animal room to watch the cat, where once again the animal seemed to Poore to be "unconscious of its condition." 65 When it was taken out of its cage, the cat wandered around the room purring and rubbing up against Poore, "affording no evidence whatever of discomfort." 66 Although Poore emphasized in his notes that the cat was in good condition, he reported the infringement of the act relating to the certificates to the Home Secretary.

Two weeks later, a letter from Home Secretary Herbert Asquith was sent to the president of the Royal College of Physicians stating that "[t]he Secretary of State having carefully considered all the circumstances of the case had decided that Dr. Fenwick's license ... must be revoked and the Certificate A3 held by him disallowed." ${ }^{27}$ Letters were also sent to Fenwick and to the secretary of the Association for the Advancement of Medicine by Research. ${ }^{68}$ Poore was informed about the situation that resulted from the information that he provided and for which he was to a large extent responsible. ${ }^{69}$ Poore revealed an additional infringement of the Vivisection Act later in the same month. Visiting the Brown Institution, he noted that Sherrington did not have the certification required for the experiments he performed on cats and reported the matter to the Home Secretary. ${ }^{70}$ In April 1895, the Home Office sent a long letter to Sherrington. While Home Secretary Asquith acknowledged that Sherrington had performed several experiments without holding the requisite certificates, he was ready to accept that the infringements were done "through forgetfulness." However, he stressed the "necessity of an invariable compliance with the provisions of the Act" and concluded, with regret, "that he feels bound to mark his sense of [Sherrington's] neglect to observe the law" by postponing for a month the further consideration of

63. Letter on behalf of the Secretary of State to Professor Wright, December 7, 1895, HO 156/9, 524.

64. Poore, "Dr. Poore's 1896 Report," 10.

65. Poore, "Dr. Poore's 1896 Report," 11.

66. Poore, "Dr. Poore's 1896 Report," 11.

67. Letter on behalf of the Secretary of State to the President of the Royal College of Physicians, January 31, 1895, HO 156/9, 193.

68. Letter on behalf of the Secretary of State to the Secretary of the Association for the Advancement of Medicine by Research, January 31, 1895, HO 156/9, 192; Letter on behalf of the Secretary of State to Fenwick, January 31, 1895, HO 156/9, 190.

69. Letter on behalf of the Secretary of State to George W. Poore, January 31, 1895, HO 156/9, 194.

70. Poore, "Dr. Poore's 1896 Report," 4. 
certificates submitted by Sherrington. ${ }^{71}$ On May 11, 1895, Kenelm Digby, permanent undersecretary, informed Sherrington that his license was renewed and his certificates allowed. ${ }^{72}$

This example shows that, contrary to the claim made by historian Richard French (1975), the Vivisection Act's enforcement was not directed solely toward the weaker and less influential members of the experimental world, as Sherrington had been penalized despite his position as the general secretary of the International Physiological Society. ${ }^{73}$ Other examples of civil servants confronting senior scientists exist. For instance, the Home Office denied a certificate to established physiologist Gerald Yeo. ${ }^{74}$ The latter complained to his colleagues that his work had been obstructed by the Home Office (Sharpey-Schafer 1927, 75).

In spite of the infringements made by Wright, Fenwick, and Sherrington during 1895, Poore mentioned only two irregularities when submitted his annual report to Parliament. (He probably omitted from his count Wright's case, which did not entail punitive measures.) Poore maintained that "the licensees have, as usual, manifested strict loyalty to the letter and spirit of the Act." 75 In the same protective tone, when Poore reported seven cases of licensees "inadvertently overstepping their powers under the Act" during 1897, he noted that "the facts were recorded in good faith by the licensees themselves, and in each case they expressed their great regret at the inadvertence."76 Inspector Russell expressed the same confidence in the experimenters when he wrote to the undersecretary of state that he found that "many licensees had difficulty in understanding the Act," but he also "saw nothing to indicate that any of them had failed to comply with it or desired to evade its provisions."77

The annual reports composed by the inspectors and presented to the House of Commons by the home secretary routinely portrayed the experimenters in a positive, cooperative light and downplayed their misdeeds. Nonetheless, the official reports did not give details about important aspects of the communications between inspectors and experimenters behind the scenes. The inspectors' visitation reports were confidential and so was the frequent correspondence between the home secretary and the inspectors. The general public, including members of anti-vivisection societies, could only learn about the administration of the Vivisection Act from the published annual reports and the sporadic references to the subject made by the home secretary during parliamentary debates that found their way to the newspapers.

The way in which inspection was carried out was so obscure that it led antivivisection protestors to doubt that any inspection was taking place. A contributor to the Zoophilist $(1887,74)$ complained that, while inspectors of schools were so meticulous as to record the beginning and ending times of each of their school visits, "there is not even the pretense of registering the so-called inspectors' visits." None of the

71. Kenelm Digby to Charles Sherrington, April 3, 1895, HO 156/9, 259.

72. Kenelm Digby to Charles Sherrington, May 11, 1895, HO 156/9, 316.

73. Compare to French 1975, 208.

74. Godfrey Lushington to Gerald Yeo, March 13, 1884, HO 156/2, 26.

75. Experiments on Living Animals, 1896, H.C. 330, 3.

76. Experiments on Living Animals, 1898, H.C. 215, 695.

77. James Russell to the undersecretary of state, March 5, 1900, HO 144/451/B30824. Inspectors in other fields also felt they had to educate and simplify the act for people (Pellew 1974, 190-91). 
inspectors, he contended, "has condescended to afford the nation which had paid their salary the slightest information as to when or where-if ever-they have inspected a physiological laboratory at all" (74). A reviewer of the 1893 annual report frustratingly commented that "it would have been much more to the purpose if Dr. Poore had said something more of the nature of the 'experimental work' itself, something of the fate of the animal on which it is carried out; but this is just what he avoids" (Zoophilist 1894, 24). The Zoophilist $(1897,47)$ made the accusation that the annual report was nothing but "anaesthesic to public opinion" and that "the inspector flounders deeper and deeper into the morass of insincerity as he strives his hardest to screen his clients, the vivisectors, from the public odium and condemnation they so richly deserve." MP John MacNeill claimed that "the inspections of the vivisection laboratories were absolutely worthless" and complained that the home secretary "had refused to give a return showing the number of times the inspectors visited the laboratories and describing what they saw." ${ }^{78}$ But his call was never answered; inspectors did not describe what they saw and published only their final judgments on pain.

Since the Home Office did not disclose to the general public much of the routine administration of the act, critics of the act concluded that experimenters dictated what the inspectors wrote in their reports. When the Derby Daily Telegraph and Reporter $(1880,3)$ summarized one of the annual reports to its readers, it added that "the reporting officer, however, depends upon the assurance of the experimenters that in none of the other experiments under the certificates was any appreciable suffering inflicted." The Zoophilist $(1897,47)$ pronounced the claim that the inspector "only knows what the vivisectors tell him." And the chaplain of Lucas's Hospital in Wokingham, Joseph Stratton $(1894,91)$, claimed that it was "highly probable that he [the inspector] knows very little as to what really goes on in the torture-chambers up and down the country."

While anti-vivisection advocates complained that the inspectorate was inactive, physiologists felt it was overactive. In 1881, the Physiological Society delivered a report about the Vivisection Act, which testified to the impact the act had on vivisection practitioners. The report was drafted by a committee composed of Lauder Brunton, Philip Henry Pye-Smith, and Gerald Yeo. The committee advised urging the Home Office to change the administration of the act, "so as to make it practically a registration act, with the double safe-guard against possible abuse of the 'recommendations,' and of the 'inspection' which it provides." The report contained findings from a survey based on thirty respondents (out of seventy questionnaires sent) showing that there has been

no absolute refusal of a license, but, that refusals of both licenses and certificates have repeatedly been revoked, only after long delay and by the help of strong pressure upon the Home Office: while some certificates have been absolutely refused. Moreover, in several cases, experiments have been prevented owing to intimation that licenses or certificates would certainly not be granted.

The committee reported about seven cases of refusal to allow certificates, six cases of "injurious delay, often amounting to practical refusal," and five cases in which

78. 52 Parl. Deb. (4th ser.) (1897) col. 373. 
experimenters were deterred from applying. ${ }^{79}$ This account reveals something important about the workings of the act: even though there were no "absolute refusals" of license applications, the Home Office's administration of the Vivisection Act, characterized by requests for application revisions and only seldom a refusal, had impacted the way physiologists approached their research. What the Physiological Society described in its report are scientists who feel discouraged by the threat of administrative action, and their realization that they must find ways to cope with the new legal-moral order at the same time as trying to adjust their needs to it.

The Home Office's published records purposely omitted the disciplinary actions taken against experimenters, such as the suspension of a license or the disallowance of a certificate, from the public eye. But other records show that, even though the inspectors' reports to the home secretary did not lead to any prosecution in the period under study, they were effective in making the experimenters adhere to the act's requirements. The inspectors' impact on the experimental setting is demonstrated also in their involvement in its design.

\section{INGENIOUS CAGES}

The inspectors did not openly advocate administrative discretion but exercised it to the fullest in the registration of places for experiments. ${ }^{80}$ Section 7 of the Vivisection Act authorized the home secretary to require the registration of places for the performance of experiments, as a condition for granting an experimentation license. The Home Office made registration mandatory, and the inspectors were in charge of processing the registration forms. The inspectors saw the experimental environment as an indication of the degree of attention being given to the well-being of animals, and, with this justification, they gained an increasing influence over the design of laboratories and animal rooms. They examined applications for the registration of such buildings, visited the laboratories nominated for such registration, and submitted their recommendations to the home secretary. Without the inspectors' approval, an experimental project could not have been accomplished.

Most notably, the Vivisection Act contributed to the declining number of private experimental laboratories. ${ }^{81}$ The General Medical Council was opposed to the registration provision when it first appeared in the bill. The council maintained that only spaces used for instructional purposes should be required to register. It argued that limiting experiments to registered places "would not only tend seriously to obstruct genuine scientific inquiry, but would also prove impossible in practice." The Council further claimed that the licenses and certificates required from the individual physiologists were enough to ensure the proper conduct of experimenters, and, therefore, "private researches, which in

79. Report of a Committee Appointed by the Physiological Society (in pursuance of the following resolution passed on 15th October, as amended and adopted by the Society at its meeting of the 8th December 1881), n.d., file SA/RDS/A/3, Wellcome Archives, London.

80. Compare to Jessica Wang's $(2005,271)$ claim that New Deal lawyers "built the case for expertise and administrative discretion as means for the flexibility necessary to manage the corporate political economy."

81. On the domestic and public domains of the laboratory, see Gooday 2008. 
competent hands might prove of the highest value to mankind ... ought by no means to be prohibited." 82 The Parliamentary Bills Committee of the British Medical Association also recommended changing the bill so that "a licensed person may register any convenient place for the purpose of experiment, and that such register shall be confidential document," accessible only to the secretary of state and appointed assistants. ${ }^{83}$ The secrecy of the registration was requested in order to avoid anti-vivisection protest.

A similar dissatisfaction with the registration requirement was voiced in a memorandum signed by the Teachers of Physiology in England, Scotland and Ireland, among whom were William Sharpey, William B. Carpenter, Michael Foster, Gerald Yeo, and Arthur Gamgee. These leading physiologists were willing to accept the restriction of teaching demonstrations, and in principle also of routine research, to registered laboratories. However, they claimed that experimenters needed flexibility to do experiments on short notice or at a distance from their laboratories, in their own houses, or elsewhere. ${ }^{84}$ Despite this opposition, the act allowed the home secretary to mandate the registration of places used for animal experimentation.

What criteria did the inspectors use to determine whether places were suitable for registration? Twice in 1899, James Russell declined to recommend places for registration "owing to defects of light and ventilation," though these animal houses "had been specially designed by architects of repute." At the University of Glasgow, he found the heating system satisfactory but traced problems in the lighting as well as in the low ceiling that could hurt the ventilation. His host, Dr. Muir, was unwilling to accept Russell's decision, stressing that an eminent architect had designed the building. But Russell "could not give way." He explained to Muir that his experiments would require more than a hundred animals at a time "and that it was not desirable to sanction inferior animal houses in a new building to be registered for the first time." Russell and Muir finally agreed that, until an appropriate outside space could be provided, "one of the good rooms on the main flat should be used as an animal house."

That year, Russell also declined the registration application of the Medical School at the University of St. Andrews in Scotland. A few days after his visit to Glasgow, Russell met with a physiologist named Harris and an anatomist named Musgrove in order to inspect the premises at the medical school. In contrast to many other establishments in which animals were housed in improvised facilities, the animal house at St. Andrews had been expressly built for this purpose. Yet Russell was dissatisfied with the space's ventilation and thought it would not be sufficient for a large number of animals. He provided Harris with a letter for the architect and the building committee, outlining his recommendations to remedy the defects he had identified. ${ }^{87}$ They made the required alterations in the plans, and Russell approved the application. ${ }^{88}$

82. General Medical Council, "Memorial," 3-4.

83. Parliamentary Bills Committee of the British Medical Association, "The Cruelty to Animals Bill," n.d., file SA/RDS/A/3, Wellcome Archives.

84. Teachers of Physiology in England, Scotland and Ireland, "Memorandum of Facts and Considerations Relating to the "Cruelty to Animals Bill," n.d., volume Pamphlets/Vivisection, file SA/RDS/A/3, 5, Wellcome Archives.

85. James Russell to the undersecretary of state, March 5, 1900, HO 144/451/B30824.

86. Russell, "Reports of Visits," 11.

87. Russell, "Inspection of Registered Places, 21.

88. Russell to the undersecretary of state, March 5, 1900. 
The inspectors' scrutiny of the experimental space extended beyond the registration process and included evaluating and mandating appropriate adjustments where necessary in the living environments of animals in physiological laboratories. George Poore described the living conditions of animals in general terms: he thought that the laboratory at University College in Cardiff "was in every way fitted for the performance of experiments," and he found the Physiological Department at Cambridge "beautifully clean and the animals most comfortable." 89 Russell, perhaps due to his experience in public health administration, was more detailed in his explanations. In a visit to the Pathological Department at the University of Aberdeen, Russell was impressed by an "ingenious cage with a false floor for the sake of dryness," which accommodated four guinea pigs. ${ }^{90}$ Other senses were also sometimes involved: Russell reported that the animals in the Materia Medica Department at the University of Edinburgh were very well cared for and noted that there was "no odour in the rooms." 91

Rather then being "a mere formality once officially requested" (French 1975, 283), each registration application was carefully considered by the inspectors, and their views had an important impact on the experimental space as experimenters gradually incorporated the inspectors' guidelines in the design and operation of their research facilities. Experimenters consulted Russell about appropriate arrangements for holding experimental subjects, and Russell testified that he was frequently asked for advice "regarding improved methods of construction and warming of houses for animals." 92 By the turn of the twentieth century, registration was becoming a marker of rigorous research endeavor. For the pharmaceutical manufacturer Burroughs Wellcome and Company, registering laboratories for vivisection had become a matter of principle. It was essential in order to both accomplish its commercial plans of drug production and to assert its legitimacy as a research institution among the established physiological laboratories that were mainly associated with medical schools and hospitals.

Historian E. M. Tansey's (1989, 23) study of Wellcome's registration process shows how the registration requirement became a tool in the hands of medical research gatekeepers who wished to prevent commercial companies from enjoying professional status. Early in the registration procedures and again during the examination of its 1901 application, the Home Office suggested that Henry Wellcome keep the production of the company's drugs in his facilities but conduct the related experimentation in laboratories that were already registered with established research institutions. Wellcome rejected this advice, complaining that it entailed an unnecessary burden on his staff. He also referred to the symbolic element in the registration process: "I desire to come openly under the existing law, and to have my Physiological Research Laboratories registered under the act controlling animal experiments" to be "regularly inspected like other laboratories of the same kind." ${ }^{193}$

89. Poore, "Dr. Poore's 1895 Report," 2, 3.

90. Russell, "Russell's 1895 Report," 8.

91. Russell, "Russell's 1896 Report," 3.

92. Russell to the undersecretary of state, March 5, 1900.

93. Draft of an unsigned letter to Home Secretary Matthew Ridley, January 1900 [?], file WF/WPRL/ 01/02, 2, Wellcome Archives. 
The regulation of experimental spaces and their separation from scientists' private lives is part of the law's expanding oversight over spaces and behaviors. But, as Silbey and Ewick $(2003,79)$ note, the subjection of the experimental space to law had strengthened science's objective appeal and reasserted the authority of the knowledge it produced. However, the regulation of animal experimentation shows that the law not only contributed to the image of science but also eased public critique of its practices. The Vivisection Act also shaped core methods of medical research such as witnessing and made bureaucrats into actors in the coproduction of cruelty-free facts.

\section{MODEST WITNESSES FOR CRUELTY-FREE FACTS}

The inspectors were responsible for shaping the experimental space as an ethical environment, and their image was designed to bear witness to the lawful formation of its products. Vivisection inspectors acted as "modest witnesses," a term used by Steven Shapin and Simon Schaffer (1985, 22-79), who argue that modern experimental method necessitated a collective act of witnessing and a reporter who was accepted as a reliable provider of testimony to create an experimental fact. ${ }^{94} \mathrm{I}$ borrow this term and contend that, in the case of animal experimentation, civil servants acted as reliable reporters; through the Vivisection Act's implementation, inspectors were figures of modest witnesses who enabled the creation of an ethical scientific fact. ${ }^{95}$ The participation of inspectors as witnesses and reporters for the production of science was pushed to the extreme when they were asked to watch live experiments.

Some critics of vivisection demanded that inspectors be regularly present at the experiments. For them, examining the unused animals, or those that had already recovered from vivisection, was not enough. Moreover, as mentioned above, a constant complaint was that the annual returns published by the inspectors were based more on the scientists' own accounts of their laboratory conduct than on the inspectors' field reports. As one MP put it, "under no other system of inspection would it be allowed that the very individuals whom it was desired to keep under inspection should make their Reports unchecked to the House. An Inspector of Mines did not report on the Reports furnished to him by the owners or the workers in the mines, nor would an Inspector of Factories report on the ipse dixit of the owners or representatives of factories." 96

Public pressure forced the Home Office to consider sending inspectors to watch live experiments. In 1890, Inspector John Erichsen doubted that the Home Office could appoint inspectors whose duties would be to attend and supervise the performance of experiments. Erichsen believed that "few if any gentlemen of independent position" would undertake a mission with such an "inquisitorial character." And, on a more practical note, Erichsen predicated a problem arising from the simultaneous scheduling of experiments. Home Secretary Henry Matthews clarified at the same time that the act did not require the personal supervision of inspectors over experimentation. ${ }^{97}$ Thinking

94. Donna Haraway $(1997,23)$ readdresses the figure of the modest witness.

95. Compare to Redfield 2006.

96. 17 Parl. Deb. (4th ser.) (1893) col. 332.

97. "Memo on Inspection." 
that "one of the most unsatisfactory symptoms of the present day is the craving for incessant inspection in every function of life," Matthews rejected complaints over the limited extent of inspection made by MPs. Inspectors' presence at experiments, he claimed, was neither necessary nor possible. ${ }^{98}$ Matthews' successor, Home Secretary Herbert Asquith, reacted similarly when MP Lockwood argued that the legislature intended to insist upon personal inspection over experiments. ${ }^{99}$

Others proposed allowing representatives of the public to watch the experiments. Alpheus Morton, MP for Peterborough, expressed this idea during a debate in the House of Commons in 1895. Morton clarified that he did not wish to complain about the inspectors yet asserted that allowing interested people to witness experiments would reassure the public regarding whether there was any unnecessary cruelty involved. Home Secretary Asquith replied that he had no power to order public access. The inspectors, who could visit the places under parliamentary authority, were not authorized to allow entrance to anyone else. Asquith further argued that such an arrangement might interrupt the experiments, which were often of a "very delicate nature." 100 Another unsuccessful proposal was presented by MP Lockwood later in 1898: "The laboratories should be open to a limited number of university graduates and medical men, who represent the public, when experiments are to be performed, in order that they may see that they are carried out in a humane manner, and under proper anæsthetics."101

Poore and Russell witnessed some operations even though the Vivisection Act did not explicitly require them to do so. It had happened unintentionally during routine visits or occasionally following a command of the administration to watch an experiment. The inspectors were often intrigued by the scientific significance of the experiments, and, following the act's requirements, they paid close attention to the workings of anesthesia. In a visit to the Physiological Department at University College in London, Poore observed Edward Schäfer engaged in a blood pressure experiment on a dog: "The animal was as unconscious as a dead animal." 102 In October 1895, Poore saw Vaughan Harley perform an enterostomy (creating an opening in the abdominal wall) on a dog and noted that "the animal was necessarily deeply anesthetized." 103 Poore also saw J. S. R. Russell operating upon a dog at the Pathological Department at University College in London: "The dog was deeply anaesthetized and felt nothing and would be killed before recovery." 104

Inspector Russell was instructed — by the home secretary or by Poore-to witness an experiment done by Gustav Mann at the Physiological Department of the University of Edinburgh. He watched for an hour and a half and concluded: "I do not think that

98. 348 Parl. Deb. (3rd ser.) (1890) col. 780.

99. 17 Parl. Deb. (4th ser.) (1893) col. 345. Additionally, the Home Office received repetitive requests to increase the number of inspectors or assistants, including a "numerously signed" petition in 1896. Letter on behalf of the home secretary to H. J. Reid, July 4, 1895, HO 156/9, 366.

100. 34 Parl. Deb. (4th ser.) (1895) col. 763; see also The Zoophilist 1895, 205-6. The concept of a public representative in inspection was raised during the Royal Committee on Vivisection hearings (Royal Commission on Vivisection 1876, 105).

101. 63 Parl. Deb. (4th ser.) (1898) col. 542

102. Poore, "Dr. Poore's 1895 Report," 8.

103. Poore, "Dr. Poore's 1896 Report," 29.

104. Poore, "Dr. Poore's 1895 Report," 11. 
the animal suffered appreciable pain and it seemed to me that on several occasions it nearly died from excessive doses of ether." ${ }^{105}$ Russell's criticism of the uses of anesthetics came up again when visiting the Royal College of Physicians in Edinburgh in June 1894. In one room, he saw physician Ralph Stockman $(1895,1475)$ bleeding a dog from a vein in the leg and then injecting the blood under the skin, probably as part of the investigation of iron-deficiency anemia. Superintendent Diarmid Noel Paton, Dr. Miles, and two servants were also present: "The dog was much frightened and moaned and howled while under the influence of ether. ... The ether was required by the act and was the cause of all the trouble by frightening the dog."106 In this case, it was the experimenter's adherence to the Vivisection Act that made the animal suffer, and yet, for the home secretary, experiments without anesthesia were more troubling. This is one of the very few occasions in which an inspector pointed to mental distress: the dog was frightened. Later that year, the Home Office ordered Stockman to inform Russell in advance of the dates he planned to experiment without anesthesia. $^{107}$

The scientific knowledge produced by late nineteenth-century physiology not only had to be accurate but also ethical. The presence of inspectors in experiments as well as their inspection visits and oversight over laboratory records were needed in order to produce ostensibly cruelty-free experimental facts. After overcoming their initial resistance to inspection, physiologists learned to use it as an ethical authorization. The presence of inspectors in laboratories, especially during experiments, aimed to reassure the British public that scientific knowledge was produced by ethically approved methods.

\section{CONCLUSION}

When British inspectors under the Vivisection Act 1876 entered late nineteenthcentury physiology laboratories, they guided the experimenters on how to produce knowledge lawfully and in line with contemporary humanitarian sensibilities to animal pain - that is, with the ostensibly minimal infliction of pain necessary to achieve the objects of the experiments. By examining the work of two chief Home Office inspectors in the act's first decades, this article has examined their roles in both the scientific and bureaucratic worlds. In spite of the inspectors' undeniable support of the experimental enterprise, they developed a nuanced relationship with the physiologists whose work they oversaw through the routine administration of the act. The inspectors cultivated close ties with experimenters. They formally and informally advised physiologists on the act's interpretation, and they enforced its requirements for vivisection practitioners to obtain licenses and certificates for their work. The inspectors also exercised judgments about animal pain and the proper conditions for an experimental space, concurrently compelling the physiologists they visited to engage with the same questions.

105. Russell, "Russell's 1895 Report," 2.

106. Russell, "Russell's 1895 Report," 3.

107. Secretary of State to Ralph Stockman, October 23, 1894, HO 156/9, 10. 
In implementing the Vivisection Act, inspectors drew upon Victorian humane principles to redesign certain scientific practices and thereby create knowledge about nature that was produced with ethically acceptable methods, which I have termed ethical scientific facts. In Britain and other Western societies today, there is an ever-increasing regulation of experiments on animals and humans. Recognizing how law and science coproduce ethical scientific facts helps us better understand the evolving integration of legal norms in scientific research and raises questions as to the status of "unethical" scientific knowledge. My examination of the work of vivisection inspectors shows how scientific practice and legal standards coproduce knowledge in the age of medical research regulation. In the case of late nineteenth-century animal experimentation, ethically acceptable knowledge about physiology was knowledge produced lawfully, with supposedly minimal pain to laboratory animals. Through their everyday encounters with licensees and caged animals, vivisection inspectors interweaved law, ethics, and the production of scientific facts.

\section{REFERENCES}

Avraham, Ronen, and Max Schanzenbach. 2015. "The Impact of Tort Reform on Intensity of Treatment: Evidence from Heart Patients." Journal of Health Economics 39: 273-88. https:// doi.org/10.1016/j.jhealeco.2014.08.002.

Bartrip, P. W. J. 1983. "State Intervention in Mid-Nineteenth Century Britain: Fact or Fiction?" Journal of British Studies 23, no. 1: 63-83.

Bates, A. W. H. 2017. Anti-Vivisection and the Profession of Medicine in Britain: A Social History. Basingstoke, UK: Palgrave Macmillan. http://www.palgrave.com/de/book/9781137556967.

Bora, Alfons. 2010. "Technoscientific Normativity and the 'Iron Cage' of Law." Science, Technology, and Human Values 35, no. 1: 3-28.

Bourke, Joanna. 2014. The Story of Pain: From Prayer to Painkillers. New York: Oxford University Press.

Bucchi, Massimiano, and Federico Neresini. 2007. "Science and Public Participation." In The Handbook of Science and Technology Studies, 3rd ed., edited by Edward J. Hackett, Olga Amsterdamska, Michael E. Lynch, and Judy Wajcman, 449-72. Cambridge, MA: MIT Press.

British Medical Journal. 1881. "The Charge against Professor Ferrier under the Vivisection Act: Dismissal of the Summons." 2, no. 1090: 836-42.

—. 1886. "George Busk, F.R.S." 2, no. 1337: 346.

—. 1894. "Birthday Honours." 1, no. 1744: 1216-17.

—. 1904. "George Vivian Poore, M.D., F.R.C.P., Emeritus Professor of Medicine, University College, London." 2, no. 2292: 1544-46.

1905. "The Late Dr. Poore." 1, no. 2321: 1398.

Burnett, D. Graham. 2010. Trying Leviathan: The Nineteenth-Century New York Court Case That Put the Whale on Trial and Challenged the Order of Nature. Princeton, NJ: Princeton University Press.

Carpenter, Daniel. 2001. The Forging of Bureaucratic Autonomy: Reputations, Networks, and Policy Innovation in Executive Agencies, 1862-1928. Princeton, NJ: Princeton University Press.

Clark, Michael, and Catherine Crawford, eds. 1994. Legal Medicine in History. Cambridge, UK: Cambridge University Press.

Coleman, William, and Frederic L. Holmes, eds. 1988. The Investigative Enterprise: Experimental Physiology in Nineteenth-Century Medicine. Berkeley: University of California Press.

Cromwell, Valerie. 1966. "Interpretations of Nineteenth-Century Administration: An Analysis." Victorian Studies 9, no. 3: 245-55.

Crook, Tom. 2007. "Sanitary Inspection and the Public Sphere in Late Victorian and Edwardian Britain: A Case Study in Liberal Governance." Social History 32, no. 4: 369-93.

Derby Daily Telegraph and Reporter. 1880. "Report on Vivisection." June 3. 
Dicey, A. V. 1905. Lectures on the Relation between Law and Public Opinion in England during the Nineteenth Century. London: Macmillan and Company.

Dror, Otniel E. 1999. "The Affect of Experiment: The Turn to Emotions in Anglo-American Physiology, 1900-1940." Isis 90, no. 2: 205-37.

Erichsen, John Eric. 1879. "The Antivivisectionists and the Progress of Modern Surgery." British Medical Journal 2, no. 985: 794.

Ernst, Daniel. 2014. Tocqueville's Nightmare: The Administrative State Emerges in America, 1900-1940. Oxford: Oxford University Press.

French, Richard. 1975. Antivivisection and Medical Science in Victorian Society. Princeton, NJ: Princeton University Press.

Geison, Gerald L. 1978. Michael Foster and the Cambridge School of Physiology: The Scientific Enterprise in Late Victorian Society. Princeton, NJ: Princeton University Press.

Golan, Tal. 2007. Laws of Men and Laws of Nature: The History of Scientific Expert Testimony in England and America. Cambridge, MA: Harvard University Press.

Gooday, Graeme. 2008. "Placing or Replacing the Laboratory in the History of Science?" Isis 99, no. 4: 783-95. https://doi.org/10.1086/595772.

Grodin, Michael A. 1995. "Historical Origins of the Nuremberg Code." In The Nazi Doctors and the Nuremberg Code: Human Rights in Human Experimentation, edited by George J. Annas and Michael A. Grodin, 121-43. New York: Oxford University Press.

Guerrini, Anita. 2003. Experimenting with Humans and Animals: From Galen to Animal Rights. Baltimore, MD: Johns Hopkins University Press.

—. 2008. "Animal Experiments and Anti-Vivisection Debates in the 1820s." In Frankenstein's Science: Experimentation and Discovery in Romantic Culture, 1780-1830, edited by Christa Knellwolf and Jane Goodall, 71-86. Aldershot, UK: Ashgate.

Hamilton, Susan, ed. 2004. Animal Welfare and Anti-Vivisection 1870-1910: Frances Power Cobbe. London: Routledge.

Hamlin, Christopher. 1986. "Scientific Method and Expert Witnessing: Victorian Perspectives on a Modern Problem." Social Studies of Science 16, no. 3: 485-513.

Haraway, Donna. 1997. Modest_Witness@Second_Millennium. FemaleMan_Meets_OncoMouse: Feminism and Technoscience. New York: Routledge.

Harrison, Brian. 1973. "Animals and the State in Nineteenth-Century England." English Historical Review 88, no. 349: 786-820.

Hilgartner, Stephen, Clark Miller, and Rob Hagendijk, eds. 2015. Science and Democracy: Making Knowledge and Making Power in the Biosciences and Beyond. New York: Routledge.

Home Office. 1980. "Memorandum Submitted by the Home Office, 13 December 1979." In House of Lords, Report of the Select Committee on the Laboratory Animals Protection Bill, vol. 2. London: Her Majesty's Stationery Office.

Jasanoff, Sheila. 1990. The Fifth Branch: Science Advisers as Policymakers. Cambridge, MA: Harvard University Press.

. 1996. "Beyond Epistemology: Relativism and Engagement in the Politics of Science." Social Studies of Science 26, no. 2: 393-418.

- 1997. Science at the Bar: Law, Science and Technology in American Law. Cambridge, MA: Harvard University Press.

Kean, Hilda. 1995. "The 'Smooth Cool Men of Science': The Feminist and Socialist Response to Vivisection." History Workshop Journal 40: 16-38.

- 1998. Animal Rights: Political and Social Change in Britain since 1800. London: Reaktion Books.

Kelly, Catherine, and Imogen Goold, eds. 2009. Lawyers' Medicine: The Legislature, the Courts and Medical Practice, 1760-2000. Oxford: Hart Publishing.

Kete, Kathleen. 1995. The Beast in the Boudoir: Petkeeping in Nineteenth-Century Paris. Berkeley: University of California Press.

Lansbury, Coral. 1985. The Old Brown Dog: Women, Workers, and Vivisection in Edwardian England. Madison: University of Wisconsin Press.

MacDonagh, Oliver. 1958. "The Nineteenth-Century Revolution in Government: A Reappraisal." The Historical Journal 1, no. 1: 52-67. 
MacLeod, Roy. 1965. "The Alkali Acts Administration, 1863-84: The Emergence of the Civil Scientist." Victorian Studies 9, no. 2: 85-112.

1968. "Government and Resource Conservation: The Salmon Acts Administration, 1860-1886." Journal of British Studies 7, no. 2: 114-50. https://doi.org/10.2307/175298.

—, ed. 2003. Government and Expertise: Specialists, Administrators and Professionals, 1860-1919. Cambridge, UK: Cambridge University Press.

Mills, Catherine. 2008. "The Emergence of Statutory Hygiene Precautions in the British Mining Industries, 1890-1914." The Historical Journal 51, no. 1: 145-68.

Mott, F. W., and C. S. Sherrington. 1894. "Experiments upon the Influence of Sensory Nerves upon Movement and Nutrition of the Limbs. Preliminary Communication." Proceedings of the Royal Society of London 57: 481-88.

Murray, George R. 1896. "Some Effects of Thyroidectomy in Lower Animals." British Medical Journal 1, no. 1830: 204-6.

Novak, Steven J. 1973. "Professionalism and Bureaucracy: English Doctors and the Victorian Public Health Administration." Journal of Social History 6, no. 4: 440-62.

Novak, William J. 1996. The People's Welfare: Law and Regulation in Nineteenth-Century America. Chapel Hill: University of North Carolina Press.

Oliver, Thomas. 1891. "Goulstonian Lectures on Lead Poisoning in Its Acute and Chronic Manifestations." British Medical Journal 1, no. 1575: 505-8.

Parris, Henry. 1960. "The Nineteenth-Century Revolution in Government: A Reappraisal Reappraised." The Historical Journal 3, no. 1: 17-37.

Pellew, Jill. 1974. "The Home Office and the Explosives Act of 1875." Victorian Studies 18, no. 2: 175-94.

1982. The Home Office, 1848-1914: From Clerks to Bureaucrats. Rutherford, NJ: Fairleigh Dickinson University Press.

Pemberton, Neil, and Michael Worboys. 2007. Mad Dogs and Englishmen: Rabies in Britain 1830-2000. Basingstoke, UK: Palgrave Macmillan.

Rajan, Kaushik Sunder, ed. 2012. Lively Capital: Biotechnologies, Ethics, and Governance in Global Markets. Durham, NC: Duke University Press.

Redfield, Peter. 2006. "A Less Modest Witness: Collective Advocacy and Motivated Truth in a Medical Humanitarian Movement on JSTOR." American Ethnologist 33, no. 1: 3-26.

Rey, Roselyne. 1998. The History of Pain. Cambridge, MA: Harvard University Press.

Rhodes, Gerald. 1981. Inspectorates in British Government: Law Enforcement and Standards of Efficiency. London: Allen \& Unwin for the Royal Institute of Public Administration.

Ritvo, Harriet. 1987. The Animal Estate: The English and Other Creatures in the Victorian Age. Cambridge, MA: Harvard University Press.

Royal Commission on Vivisection. 1876. Report of the Royal Commission on the Practice of Subjecting Live Animals to Experiments for Scientific Purposes; with Minutes of Evidence and Appendix. London: Eyre \& W. Spottiswoode.

- 1907. Appendix to First Report of the Commissioners: Minutes of Evidence, October to December, 1906. London: Wyman and Sons.

1912. Final Report of the Royal Commission on Vivisection. London: Wyman and Sons.

Shapin, Steven. 2010. The Scientific Life: A Moral History of a Late Modern Vocation. Chicago: University of Chicago Press.

Shapin, Steven, and Simon Schaffer. 1985. Leviathan and the Air-Pump: Hobbes, Boyle, and the Experimental Life. Princeton, NJ: Princeton University Press.

Sharpey-Schafer, Edward. 1927. "History of the Physiological Society during Its First Fifty Years, 1876-1926." Journal of Physiology 64, no. 3: 1-76.

Shevelow, Kathryn. 2009. For the Love of Animals: The Rise of the Animal Protection Movement. New York: Holt Paperbacks. 
Silbey, Susan, and Patricia Ewick. 2003. "The Architecture of Authority: The Place of Law in the Space of Science." In The Place of Law, edited by Austin Sarat, Lawrence Douglas, and Martha Merrill Umphrey, 75-108. Ann Arbor: University of Michigan Press.

Stratton, Joseph. 1894. "Inspectors under the Vivisection Act." The Zoophilist, October.

Stockman, Ralph. 1895. "Observations on the Causes and Treatment of Chlorosis." British Medical Journal 2, no. 1824: 1473-76.

Tansey, E. M. 1989. "The Wellcome Physiological Research Laboratories 1894-1904: The Home Office, Pharmaceutical Firms, and Animal Experiments." Medical History 33, no. 1: 1-41.

Thomas, Keith. 1983. Man and the Natural World: Changing Attitudes in England, 1500-1800. London: Allen Lane.

Turner, James. 1980. Reckoning with the Beast: Animals, Pain, and Humanity in the Victorian Mind. Baltimore, MD: Johns Hopkins University.

Wang, Jessica. 2005. "Imagining the Administrative State: Legal Pragmatism, Securities Regulation, and New Deal Liberalism." Journal of Policy History 17, no. 3: 257-93.

- 2012. "Dogs and the Making of the American State: Voluntary Association, State Power, and the Politics of Animal Control in New York City, 1850-1920." Journal of American History 98, no. 4: 998-1024. https://doi.org/10.2307/41509573.

Woods, Abigail. 2004. A Manufactured Plague: The History of Foot-and-Mouth Disease in Britain. London: Earthscan.

Zoophilist. 1886. "Exit Busk, Enter Erichsen." May 1.

—. 1887. "Notes and Notices." September 1.

. 1894. "Legalized Vivisection in 1893." June 1.

. 1895. "Our Cause in Parliament: The Inspection of Vivisection Experiments." July.

. 1897. "The Inspector's Report and Vivisectors' Returns for 1896." July. 